\title{
Progressiva koalitioner, (inter)nationella influenser och kunskapsmätningar i reform- arbetet med svensk läroplan, ca 1930-1950
}

\author{
CHRISTIAN LUNDAHL *
}

\author{
Keywords \\ The International \\ Examinations Inquiry, \\ standardized test, school \\ reform, progressive coalitions, \\ curriculum theory \\ The International \\ Examinations Inquiry, \\ standardprov, skolreformer, \\ progressiva allianser, \\ läroplansteori
}

\begin{abstract}
Progressive Coalitions, (Inter)National Influences and Knowledge Assessments in Swedish Curriculum Reform, ca 19301950

Insight gained through assessments and international precedents are two strategies typically used to reform national curricula in modern educational systems. The present article illustrates how a progressive movement in Sweden used its participation in the International Examination Inquiry, not as source of ideas or methods, but as an experience of urbanity that lent credence to its proposed solutions to national educational issues. It will be shown how this movement used the IEI to promote and establish a particular institute in Sweden, the Swedish Institute for Educational Psychology (SPPI), an institute that came to re/produce a psychology-laden educational terminology directly affecting Swedish curricula for years to come.
\end{abstract}

To cite this article

Christian Lundahl, "Progressiva koalitioner, (inter)nationella influenser och kunskapsmätningar i reformarbetet med svensk läroplan, ca 1930-1950,” Nordic Journal of Educational History 1, no. 1 (2014), 59-79.

\section{Introduktion}

Inom moderna utbildningssystem förekommer det två utmärkande argumentationsstrategier för att förändra läroplaner, nämligen att hänvisa till kunskapsmätningar och att åberopa internationella idéströmningar. ${ }^{1}$ Dessa argumentationsstrategier har möjliggjorts dels genom ökade och mer preciserade kunskaper om relationen mellan skilda aspekter av utbildning och elevers studieresultat, dels genom spridningen av denna kunskap. Här har framväxten av särskilda institutioner med uppgift att analysera samhällets utveckling blivit utmärkande: institutioner vilka i sig är karaktäristiska för

\footnotetext{
* Professor of Pedagogy, Department of Pedagogical Studies, Karlstad University. Email: christian.lundahl@kau.se.

${ }^{1}$ Begreppet läroplan används här i dess mer filosofiska betydelse som en uppsättning idéer om utbildning som dominerar i ett samhälle vid en given tidpunkt. Jämför Ulf Lundgren, Frame Factors and the Teaching Process: A Contribution to Curriculum Theory and Theory on Teaching (Stockholm: Almqvist \& Wiksell, 1972); Christian Lundahl, Viljan att veta vad andra vet: Kunskapsbedömning i tidigmodern, modern och senmodern skola (Stockholm: Arbetslivsinstitutet, 2006). Jämför också Jürgen Schriewer, "Educational Studies in Europe", i Problems and Prospects in European Education, red. Elisabeth Swing, Jürgen Schriewer och François Orivel, (Westport: Praeger, 2000), 72-95; Jürgen Schriewer, "Multiple Internationalities: The Emergence of a World-Level Ideology and the Persistence of Idiosyncratic World-Views," i Transnational Intellectual Networks: Forms of Academic Knowledge and the Search for Cultural Identities, red. Christope Charle, Jürgen Schriewer och Peter Wagner (Frankfurt: Campus, 2004), 473-533.
} 
moderna samhällen. ${ }^{2}$ Inom utbildningsområdet växte dylika institutioner fram under 1900-talet.

I den här artikeln diskuteras tillkomsten av en sådan institution, Statens psykologisk-pedagogiska institut (SPPI), i relation till internationella influenser. Härvidlag uppmärksammas det svenska deltagandet i en stor internationellt jämförande examensundersökning under 1930-talet: The International Examinations Inquiry (IEI). På detta sätt kan två närbesläktade utbildningspolitiska fenomen belysas. Det ena är hur utländska influenser förändrar den pedagogiska diskussionen inom ett land och det andra är hur samma utländska influenser driver fram nationella institut för att hantera spörsmål av pedagogisk och psykologisk natur.

\section{The international examinations inquiry}

IEI var ett samarbetsprojekt, finansierat av den amerikanska forskningsstiftelsen The Carnegie Foundation, med nio deltagande länder. IEI fungerade som en arbetande internationell konferens med sammanträden vid tre tillfällen under 1930-talet. Alla länder deltog inte vid samtliga sammanträden, vilket bland annat berodde på oroligheterna i Europa. 3 Projektets syfte var att komma fram till och eventuellt enas om den mest rationella och rättvisa organiseringsmodellen för tillträde till högre grundläggande utbildning (högstadium och gymnasium). Som ett led i detta syfte önskade man också, mer eller mindre tydligt uttalat, sprida amerikanska idéer om skolan till det "gamla Europa". En av huvudfrågorna för konferenserna var om man kunde ersätta inträdesprövningar med standardiserade test. Initiativtagarna till IEI eftersträvade nämligen globala standards:

The Carnegie Foundation in the earlier years made a report on the relation between secondary schools and the college and universities, which likewise had a profound influence on education, with especial reference to standardised units of measurement, particularly those known as College Entrance Examinations.

In more recent years, the Carnegie Corporation has directly sponsored studies of a similar character, both educational and social. [...]

None of these investigations has related to countries other than the United States. But the Carnegie organisations are interested in problems of an international character, and they have chosen as one of their first topics of their attention the subject of examinations. Hence this Conference. 4

Sveriges deltagande i IEI startade 1936.5 Den svenska delegationen bestod av en statstjänsteman, en rektor och en statistikexpert. Denna lilla grupp hade understöd av

\footnotetext{
2 Anthony Giddens menar att moderna samhällen skiljer sig från traditionella samhällen bland annat genom att de moderna utmärks av en "institutionaliserad reflexivitet". Anthony Giddens, Modernity and Self-Identity: Self and Society in the Late Modern Age (Stanford: Stanford University Press, 1991).

3 Förutom Sverige ingick följande länder i IEI: England, Finland, Frankrike, Norge, Schweiz, Skottland, Tyskland och USA. Paul Monroe, red., Conference on examinations: Under the Auspieces of the Carnegie Corporation, The Carnegie Foundation and The International Institute of Teachers College Columbia University (New York: Colombia University, 1939); Martin Lawn, red., An Atlantic Crossing? The work of the International Examinations Inquiry, its Researchers, Methods and Influence (Oxford: Symposium Books. 2008).

4 Paul Monroe, red., Conference on examinations: Under the Auspieces of the Carnegie Corporation, The Carnegie Foundation and The International Institute of Teachers College Columbia University (New York: Colombia University, 1931), 1-2.

5 Monroe (1939).
} 
en större grupp bestående av forskare, lärare och tjänstemän i Sverige (se tabell 1). Den svenska kommittén publicerade tre rapporter, men ingen av dessa var författad av någon av de tre delegerade. Två av rapporterna skrevs av Frits Wigforss, vid tiden en auktoritet vad gällde konstruktion av standardprov, och den tredje rapporten togs fram av rektor Stellan Orrgård (i samarbete med Rudolf Anderberg, professor i pedagogik och psykologi vid Uppsala universitet).

\section{Utgångspunkter och överväganden}

Syftet med den här artikeln är att beskriva det svenska deltagandet i IEI och dess betydelse för tillkomsten av SPPI. ${ }^{6}$ Institutet bildades 1944 och har tidigare uppmärksammats för sin betydelse för den svenska skolan.7 Institutets tillkomst åskådliggör hur representanter för den svenska progressivismen inhämtade utländska erfarenheter och perspektiv som de sedan använde i argumentationen för reformering av läroplanen och förslag till förändring av den svenska skolans organisation. De använde sina internationella perspektiv i en "diskursiv koalition" med lärarförbund och likasinnade politiska representanter som en dynamisk strategi för att utmana traditionell utbildning och dess företrädare. ${ }^{8}$ Koalitionens nationella och internationella dynamik gör det möjligt att undersöka hur man använde sig av internationell idéimport för att argumentera för nationella läroplansreformer.

Ett vanligt angreppssätt när man analyserar effekter av internationellt utbyte är att undersöka internationella influenser i nationella diskurser i termer av borrowing och lending. ${ }^{9}$ Men när man läser de svenska rapporterna från IEI och studerar den svenska gruppens sammansättning är det dock tydligt att de inte avviker från den rådande svenska diskussionen. ${ }^{10}$ De lånade med andra ord åtminstone inte själva idén om att

\footnotetext{
6 Artikeln bygger på studier av hur IEI framträder i statliga utredningar, propositioner, motioner och riksdagsbeslut samt i sex stora lärartidskrifter från 1930-talets början till 1950-talet. Lärartidningarna är Svensk lärartidning, Tidningen folkskolan, Svensk skoltidning, Tidning för Sveriges Läroverk, Skola och samhälle, Rostads elevförbunds årsskrift. Urvalet i riksdagstryck och tidningsnummer utgår ifrån tidpunkt för fattade beslut om SPPI och tidpunkten för de konferenser IEI arrangerade. Källmaterialet omfattar även av Nils Hänningers privata arkiv, framför allt brev och hans samling pressklipp. Jag har även gått igenom SPPI:s arkiv med fokus på institutets produktion de tidigare åren. IEI:s rapporter som publicerades av Föreningen för psykologisk-pedagogiska institutet har också använts. Undersökningen har genomförts inom ramen för en forskarassistenttjänst finansierad av Vetenskapsrådet 2008-2012. Föreliggande artikel är en omarbetad översättning av Christian Lundahl, "Inter/National Assessments as National Curriculum: The Case of Sweden”, i Martin Lawn red., An Atlantic Crossing? The work of the International Examinations Inquiry, its Researchers, Methods and Influence (Oxford: Symposium Books. 2008), 157-80.

7 T.ex. Lundahl (2006).

8 Björn Wittrock, Peter. Wagner och Helmut Wollman, "Social Science and the Modern State: Policy Knowledge and Political Institutions in Western Europe and the United States," i Social Sciences and Modern States. National Experiences and Theoretical Crossroads, red. Peter Wagner et al. (Cambridge: Cambridge University Press, 1991), 28-85. En diskursiv koalition handlar om hur olika aktörer förenar sig kring en diskurs och tillsammans bidrar till att göra denna hegemonisk. Detta illustreras väl i exempelvis Jürgen Schriewers forskning, där det beskrivs hur tyska forskare från den filosofiska fakulteten under mellankrigsperioden ingår en diskursiv koalition med preussiska skoladministratörer och representanter från gymnasieskolan i syfte att bekämpa ett specifikt disciplinärt och praktiskt hot mot koalitionens syn på utbildningens organisering och syfte. Hotet kom från en annan koalition bestående av vänsterpolitiker, representanter för experimentell psykologi och pedagogik samt lärare för de lägre skolåren. Genom att gå ihop kunde den förra koalitionen få bättre gehör för argumenten att utbildningssystem skulle bygga på socialhistoriska reflektioner och epistemologi, och därmed stoppa utvecklingen av ett mer sammanhållet utbildningssystem. Den gamla skolan bestod med flera parallella utbildningsvägar som främst tjänade den högre utbildningens syften respektive ett konservativt samhälles behov av lågutbildad arbetskraft. Därigenom kunde också den filosofiska fakulteten försäkra sig om sin egen reproduktion samt utbildningsuppdragen av lärare. Jürgen Schriewers (2000) s. 75-8.

9 Gita Steiner-Kamsi, red., The Global Politics of Educational Borrowing and Lending (New York: Teachers College Press, 2004).

${ }^{10}$ Problem med examinationerna i Sverige hade aktualiserats redan av 1927 års skolutredning (SOU 1929:10).
} 
reformera examenssystemet i Sverige från den internationella arenan. Samtidigt syns tydliga spår av det internationella samarbetsorganet i svenska policydokument och i olika lärartidningar från 1930- och 1940-talen. Mot den bakgrunden bör det svenska utbytet av just dessa internationella influenser förstås på annat sätt än ett oförmedlat inlån av idéer.

Jürgen Schriewer menar att åberopanden av internationella strömningar och andra länders utbildningsväsende inte behöver vara uttryck för ursprunglig påverkan, utan kan vara ett sätt att legitimera redan existerande nationella reformförslag. ${ }^{11}$ Det är alltså möjligt att tolka åberopandet av det internationella samarbetet som ett sätt att legitimera utbildningspolitiska reformförslag som redan förelåg..$^{12}$

En sådan tolkning av internationella åberopanden stöds av tidigare forskning om den svenska delegationens rapporter från det internationella samarbetet. Från ett svenskt historiskt perspektiv är det med andra ord inte rapporterna i sig som är det mest intressanta med det svenska deltagandet i IEI. Den diskurs som kommer till uttryck i rapporterna är välkänd, och viktigare, den hade utvecklats i Sverige redan innan Sverige gick med i IEI. ${ }^{13}$ Rapporterna publicerades dock i Föreningen för psykologisk-pedagogiska institutets namn. Denna förening föregick SPPI:s tillkomst. Den fråga som styrt det empiriska arbetet i den här artikeln har därför varit vilken relation deltagandet i IEI hade till såväl föreningen som själva SPPI:s bildande. Med utgångspunkt i ett neo-institutionalistiskt perspektiv kommer jag att argumentera för att hänvisningar till IEI fungerade som en strategi för att legitimera en progressiv position inom det svenska utbildningsfältet och att SPPI blev ett av dess institutionella uttryck. ${ }^{14}$

\section{Att ta det nationella perspektivet utomlands - det svenska del- tagandet $i$ the International Examination Inquiry}

Att deltagandet i IEI hade effekter blir tydligt om vi följer den svenska delegationens olika publikationer och uttalanden. Det är emellertid tveksamt om begreppet "borrowing” passar särskilt bra för att förklara effekten av IEI i Sverige. Det var inte de internationella idéerna som slog igenom utan referenserna till det internationella sammanhanget. Svenska representanter hade besökt den tidigare IEI-konferensen i Folkstone i England 1935, men konferensen i Dinard (i Frankrike 1938) var den första där Sverige deltog som fullvärdiga medlemmar. Representanter för Sverige på Dinardkonferensen var docent Nils Hänninger, doktor Tor Jerneman och rektor Hugo Grimlund. Ordförande för den svenska kommittén var Nils Hänninger, tidigare också undervisningsråd vid Skolöverstyrelsen samt ordförande för ett bokförlag. Jerneman

\footnotetext{
11 Schriewer (2000); Schriewer (2004). Att åberopa effektivitet, modernitet och vetenskaplighet är andra sätt att ge legitimitet åt reformer. John W. Meyer och Brian Rowan, "Institutionalized Organizations: Formal Structure as Myth and Ceremony," The American Journal of Sociology, 83, no. 2 (1977), 340-63.

12 Carol Ann Spreen har dock i nutida exempel sett att hänvisningar till den internationella scenen vid ett visst tillfälle inte längre fungerar lika bra för att legitimera politiska reformer: "It is precisely when ideas begin to take hold and become national policies that they must confront cultural beliefs, practices, and local understandings; then the international argument loses weight”. Carol Ann Spreen,"Appropriating Borrowed Policies: Outcomes-Based Education in South Africa," i The Global Politics of Educational Borrowing and Lending, red. Gita Steiner-Kamsi (New York: Teachers College Press, 2004), 112.

13 Se även Lundahl (2006); Christian Lundahl, Varför nationella prov? Framväxt, dilemman, utmaningar (Lund: Studentlitteratur, 2009).

14 Meyer och Rowan (1977); Schriewer (2000); Schriewer (2004). Utbildningsfält i den här artikeln avser ett diskursivt och realpolitisk område i besittning av tre huvudaktörer: politiker och skoladministratörer, pedagogiska forskare samt lärare och dess representanter. Se vidare Lundahl (2006).
} 
var expert på statistik vid socialstyrelsen och Grimlund var rektor på Vasa realskola i Stockholm. Det var på Dinard-konferensen den svenska delegationen kom att presentera sitt arbete.

Av stenografianteckningarna från Dinard-konferensen framgår att svenskarna var där för att informera om sitt arbete och om utvecklingen i Sverige snarare än att ta intryck av de andra länderna. ${ }^{15}$ Redan i sin introduktion till presentationen tog Hänninger avstamp i den nationella kontexten och "essential problems for the time being within our educational world in Sweden". ${ }^{16}$ Han redogjorde sedan för Frits Wigforss arbete och poängterade att Wigforss "is also engaged in another investigation of the same kind, on the basis of a wider material". Hänninger nämner att Wigforss andra engagemang rör en viktig statlig utredning (SOU 1938:29) om att avskaffa inträdesprov till realskolan och ersätta dem med avgångsbetygen från folkskolan. ${ }^{17} \mathrm{En}$ förutsättning för att betygen skulle kunna fylla denna funktion var att de sattes på ett rättvist sätt, det vill säga att de betydde lika mycket på alla skolor. Med andra ord att de var standardiserade. I IEI-rapporten visade Wigforss att korrelationen mellan resultaten på inträdesprov och senare skolframgångar generellt sett var låg. ${ }^{18} \mathrm{Om}$ standardiserade betyg kunde uppvisa ett starkare samband med skolframgång, då skulle inträdesproven ha spelat ut sin roll.

I introduktionen nämner Hänninger också andra målsättningar med de svenska undersökningarna. Han utgick från aktuella problem inom det svenska utbildningssystemet, nämligen avgångsexaminationen på gymnasiet. Han menade att den stora utmaningen var att hitta en examensform som kunde avgöra om studenten borde gå ut i arbetslivet, och i så fall till vilket yrke, eller om studenten var lämpad för studier vid universitetet. Vilken utformning examen skulle fă hade studerats genom en vid tiden ovanlig metod som kan liknas vid en attitydundersökning. ${ }^{19}$ Hänninger hävdade att ur ett svenskt perspektiv var inte problemet om examinationerna skulle vara muntliga eller skriftliga. ${ }^{20}$ Det stora problemet var att lärarna inte ville låta sig påverkas av expertis i sina bedömningar.

När sedan Tor Jerneman tog över presentationen av de svenska resultaten blir detta ännu tydligare. Jerneman anförde vad som kan hävdas vara huvudproblemet i den svenska bedömningsdiskursen vid tiden. Problemet med att standardisera betyg, vare sig det gällde folkskolan eller gymnasiet, låg $\mathrm{i}$ "the fact that the individual teacher does not like to drop his own judgment of the pupils' ability in order to base the marks on the test". ${ }^{21}$ Detta var ett tydligt resultat av Wigforss studie. Hur skulle man göra för att lärarna skulle känna att de fortfarande gjorde bedömningarna samtidigt som de standardiserades externt? De två studier som svenskarna presenterade hade på olika sätt brottats med frågan och det typiskt svenska perspektivet kan sägas ha varit att sätta både lärarna och undervisningen i förgrunden för frågor om bedömning och

\footnotetext{
15 Se Monroe (1939).

16 Monroe (1939), 207.

17 Monroe (1939), 208.

18 Monroe (1939), 210; Frits Wigforss, The entrance examination in view of later school performances (Stockholm: Norstedts, 1937).

19 Stellan Orrgård, High school entrance-tests and the work of the primary-school: A Swedish nation-wide investigation in 1936 (Stockholm: Norstedts, 1937).

20 Monroe (1939), 209.

${ }^{21}$ Monroe (1939), 211.
} 
examination. Även Hugo Grimlunds studie, vars resultat endast tentativt redovisades under konferensen, utgick ifrån ett lärarperspektiv. Han hade studerat lärarnas missnöje med den statligt upprättade examinationen i språk. Examinationen "compel teachers to exercise a grammatical drill for years before the examination", hävdade Grimlund. ${ }^{22}$ I en jämförelse med de andra ländernas presentationer handlade det svenska perspektivet inte lika mycket om rättvisa bedömningar och likvärdiga livschanser (meritokrati) utan om effekterna av externa bedömningar på lärares arbete.

Mot den bakgrunden och i ljuset av vad Hänninger och Wigforss tidigare skrivit kan deltagandet i IEI inte sägas ha givit upphov till någon förändring av den svenska bedömningsdiskursen. Effekten låg utanför den textuella diskursen. Erfarenheten av att ha arbetat i ett internationellt nätverk, att vara världsvan, kom att användas som ett sätt att legitimera den egna inhemska progressiva linjen där mycket av bedömningsmakten ligger kvar hos läraren. För att förstå den svenska diskursen i 1930-talets utbildningssystem kan man titta närmare på just Föreningen för psykologiskpedagogiska institutet, dess medlemmar, och vilken funktion institutet fyllde. Efter att ha undersökt dessa aspekter närmare återkommer jag till frågan om vilka direkta effekter IEI hade på den svenska läroplanen.

\section{Förändring i ett litet land - ett progressivt nätverks fältarbete}

The work of the Swedish Committee has not proceeded as far as in certain other countries. This in the first place depends on the fact that we were not able to take up our work at the beginning of the International Institute Examinations Inquiry but entered it about 1936. It is also because of the situation in a small country where there are not so many persons who are at the same time qualified for a certain investigation and unprevented from other occupations to take it up. ${ }^{23}$

Ovanstående citerar Hänninger under Dinard-konferensen och illustrerar en omständighet typisk också för de två andra nordiska länderna i IEI. Den kompetens som var nödvändig för att genomföra projektet var fördelad över ett ganska litet antal personer, vilka också hade flera andra åtaganden. För svenskt vidkommande återfinns ett antal namn i flera olika texter och sammanhang från 1930- och 1940-talet, exempelvis Nils Hänninger, Frits Wigforss, Hugo Grimlund och Stellan Orrgård. De personifierade en progressiv kraft i svensk utbildning, informellt ledd av Anna Sörensen, rektor för lärarutbildningen i Stockholm. Sörensen och Hänninger skrev läroböcker tillsammans och de ingick i flera olika pedagogiska föreningar. De var båda redaktörer för den välrenommerade tidskriften Skola och samhälle. Hänninger, Wigforss och Grimlund delade också ett intresse för att medverka i internationella nätverk. Exempelvis reste de tillsammans med Sörensen till det 14:e Nordiska skolmötet $1935 .{ }^{24}$ Dessa fyra var också frekventa skribenter i en annan tidskrift: Rostads elevförbunds årsskrift.

Om man ägnar Hänninger och Wigforss lite särskild uppmärksamhet märks att de representerade en progressivism som kom till uttryck som ett program för lärarprofessionalism. Det perspektivet har sina rötter i den så kallade Rostadandan (Rostad

\footnotetext{
22 Monroe (1939), 265.

23 Hänninger i Monroe (1939), 207.

24 Viktor Fredriksson, red., Svenska folkskolans historia: vol. V: Det svenska skolundervisningsväsendet 1920-1942 (Stockholm: Albert Bonniers förlag, 1950), 406.
} 
var lärarseminariet i Kalmar) vilken kan beskrivas som en filantropisk övertygelse om den självreglerade och ansvarsfulla ungdomen. För att fostra sådan ungdom behövdes lärare som själva hade erfarenheter av ansvar och autonomi. ${ }^{25}$ En sådan uppfattning fanns förstås på andra håll i skolsverige men hade vid Rostad en stark institutionell bas.

Det var i egenskap av lektor i psykologi, pedagogik och matematik på Rostads folkskoleseminarium i Kalmar som Wigforss började utveckla standardprov i matematik och aritmetik. Wigforss tog examen vid Lunds universitet 1908 och arbetade några år som gymnasielärare innan han fick ett lektorat vid Rostad. Hans första publikationer om standardprov är från början av 1930-talet, men han hade redan 1923 utgivit en handbok i hur man spelar schack. ${ }^{26}$ Schackspelarens lekfullhet och problemlösning kännetecknar både de prov Wigforss utvecklade och hans arbete med proven. Wigforss blev snabbt en populär lärare på Rostad, men han kom också att formas av Rostadsandan. ${ }^{27}$

Speciellt för Rostad var att den till skillnad från de andra folkskoleseminarierna i landet tillkommit genom en privat donation, från Cecilia Fryxells flickpension. Fryxells donation utgick från "personlig kärlek till svensk ungdom och dess fostran”, och var kopplad till den speciella, hemliknande byggnad i vilken seminariet låg. ${ }^{28}$ Institutionen fick inte "döda hemmet", och från det trygga hemmets bas skulle Rostadeleverna söka sig iväg. Ej inåtvändhet utan utåtvändhet och framåtsträvande skulle känneteckna lärarkandidaterna när de kom ut som färdiga lärare: "Ett universellt, mot mänskligheten och livet inriktat sinnelag hör med till arvet från Rostad".29 Under 1930-talet kom nya pedagogiska strömningar in under rektor Hjalmar Nilsson. Rostad utvecklades till ett progressivt pedagogiskt centrum, inte minst för prov och testutveckling, och man gav ut flera publikationer på Rostads elevförbunds förlag. ${ }^{30}$

Hänninger och Wigforss var också inspirerade av nya internationella trender inom lärarutbildningen. Medan Wigforss i sitt arbete om standardprov inspirerats av tyska författare (särskilt Johannes Kühlnels text Neubau des Rechenunterrichts) var Hänninger en av dem som förde in amerikanska tankar om utbildning i Sverige. ${ }^{31}$ Hänninger åkte till USA redan 1921 på ett statligt stipendium. I sin bok Den amerikanska uppfostringsvärlden fascineras han tydligt av icke-traditionella undervisningsmetoder och pedagogiska fenomen som projektarbete, studentinflytande/ansvar, slopandet av läxor med mera. ${ }^{32}$ En annan sak som fångade Hänningers uppmärksamhet var vad han kallade "Amerikaniseringen" - att använda utbildningsväsendet för att skapa enhetlighet i ett fragmenterat samhälle.33 Den progressiva rörelsen i

\footnotetext{
25 Rostads elevförbunds årsskrift (1930), 8-9.

26 Denna förefaller ha varit mycket populär och utkom så sent som 1957. Den har därefter reviderats av schackmästaren Gideon Ståhlberg i flera omgångar och trycktes om senast 1984.

27 Jeremy Kilpatrick och Bengt Johansson, "Standardized mathematics testing in Sweden: The legacy of Frits Wigforss," NOMAD: Nordic Studies in Mathematics Education 2, no. 1 (1994), 6-30.

28 Rostads elevförbunds årsskrift (1930), 8.

29 Rostads elevförbunds årsskrift (1930), 9.

$3^{0}$ Inga Elgqvist-Saltzman, Lärarinna, kvinna, människa (Stockholm: Carlssons förlag, 1993).

${ }^{31}$ Fredriksson (1950), 488.

32 Nils Hänninger, Den amerikanska uppfostringsvärlden: Studier och strövtåg (Stockholm: Norstedts, 1922).

33 Hänninger (1922), 80.
} 
Sverige hade samma mål för utbildningsväsendet, men såg som en förutsättning att först enhetliggöra utbildningssystemet i sig. ${ }^{34}$

Det var under sin resa till USA som Hänninger mötte Paul Monroe, ordföranden för hela IEI-projektet, och denne introducerade Hänninger personligen till det internationellt berömda Teachers' College på Columbia universitet i New York. Det är troligt att de behöll kontakt även framöver och att det var skälet till att Hänninger blev ordförande för den svenska delegationen. Första gången Hänninger refererar till IEIprojektet är i en kritisk artikel om de svenska examensförhållandena. ${ }^{35}$ Han beskriver IEI:s arbete och han för fram att det vore önskvärt om också Sverige kunde göra liknande studier.

I Hänningers personliga arkiv på Lunds universitetsbibliotek framgår det att Hänninger fick Sverige att gå med i IEI på grund av en annan av IEI:s nyckelpersoner, Isaac Kandel. Hänninger var Kandels guide i Sverige när denne var på en studieresa i Europa 1933. I ett brev daterat den 9 november 1934 informerar Kandel Hänninger om att han berättat för Paul Monroe om Hänningers intresse av att genomföra studier för IEI i Sverige. Den 20 maj följande år skrev Monroe ett brev till Hänninger, från Istanbul, i vilket han bjöd Hänninger att komma till Folkstone-konferensen i juni. Hänninger besökte konferensen och den 4 december skrev Monroe ett brev till Hänninger där han berättade att the Carnegie Corporation Board, vilka finansierade hela IEI, gått med på att ge Sverige och Finland 3000 USD om de var villiga att göra studier om ländernas respektive examensförhållanden. ${ }^{36}$

Hänninger förespråkade alltså ett amerikainspirerat enhetliggörande och en enhetsskola i stort. Wigforss huvudintresse däremot låg vid att använda prov som medel både för att åstadkomma ett mer effektivt utbildningssystem, och viktigare, ökad lärarprofessionalism. Wigforss hade redan i en artikel 1931 granskat och kritiserat välkända testmetoder för att de inte understödde elevernas eller lärarnas utveckling utan blott mätte tidigare prestationer. ${ }^{37}$ Med modernt språkbruk kritiserade han dessa test för att vara enbart summativa och inte formativa. Vad gäller den etablerade examensordningen var både Hänninger och Wigforss starkt kritiska eftersom de ansåg att den skapade stress för både lärare och elever. ${ }^{38}$ Samtidigt litade de till lärares förmåga att göra goda bedömningar. Wigforss lösning var att utveckla standardprov med det övergripande syftet att hjälpa läraren i dennes undervisning. I sin första längre artikel om dessa prov skrev han: "Men viktigt är att standardproven få bliva vad de är avsedda att vara: en mätsticka i klasslärarens hand och ej i en kontrollerande skolmyndighets." 39

Lösningen var med andra ord inte att ersätta lärares bedömningar med "objektiva" test, utan att försöka utveckla och förbättra lärarnas egna bedömningar. Wigforss

\footnotetext{
34 Bo Lindensjö och Ulf P. Lundgren, Utbildningsreformer och politisk styrning (Stockholm: HLS förlag, 2000).

35 Nils Hänninger, "Examen och skolarbete," Skola och samhälle (1932), 185-94.

36 Vid tiden motsvarande detta 12000 kronor eller runt 352 ooo kronor i 2010 års penningvärde.

37 Wigforss hade studerat test utvecklade av bland andra P. H. Ballard (som representerade England vid Dinard-konferensen), W. S. Monroe och H. Meyer. Se Frits Wigforss, "Rostads standardprov i sifferräkning," Rostads elevförbunds årsskrift (1931), 86-8; Kilpatrick och Johansson (1994), 10.

38 Hänninger (1932); SOU 1938:29, Betänkande med utredning och förslag angående intagning av elever $i$ första klassen av de allmänna läroverken och med dem jämförliga läroanstalter.

39 Frits Wigforss, ”Färdigheten i mekanisk räkning i folkskolan enligt Rostads standardtabeller," Skolan och samhälle 14 (1933), 122.
} 
argumenterade för att skolans prov och vetenskapliga test kunde korsbefrukta varandra och erbjudas läraren som ett metodiskt verktyg i dennes dagliga arbete. $4^{0}$

Det sättet att tänka om vad lärare behövde för sin professionsutveckling kastar ljus över en övergripande fråga i samtiden, nämligen nödvändigheten av en organisation som kunde introducera vetenskapliga metoder och perspektiv för läraryrket samt sammanföra praktisk och teoretisk kunskap. ${ }^{41}$ År 1934 tog Nils Hänninger och hans nätverk av progressiva tänkare således initiativ till en sådan organisation och de bildade Föreningen för psykologisk-pedagogiska institutet. Det visar sig att knappt hälften av dem som ingick i den svenska IEI-kommittén var medlemmar i denna förening (tabell 1).

\section{Föreningen för psykologisk-pedagogiska institutet - en diskursiv koalition}

I ett betänkande 1929 lämnade 1927 års skolsakkunniga ett förslag om en ny lärarutbildning..$^{22}$ Hänninger, som då var undervisningsråd vid Skolöverstyrelsen, bifogade en reservation till Skolöverstyrelsens generella remissvar på betänkandet. I sin reservation föreslog han bildandet av ett centralt institut som hade ansvar för att föra lärarutbildningens teoretiska och praktiska inslag närmare varandra. ${ }^{43}$ Hans förslag fick ett halvhjärtat mottagande från regeringen. ${ }^{44}$ Hänninger lät sig emellertid inte hindras av detta, utan bestämde sig för att tillsammans med sina personliga kontakter grunda ett sådant institut. Föreningen bildades formellt den 14 december 1934.45 Tio år senare, i november 1944 bildades Statens psykologisk-pedagogiska institut. ${ }^{46}$ Frågan här är i vilken utsträckning deltagandet i IEI användes av föreningen för förverkligandet av detta institut. Det skulle i så fall betyda att Hänninger och hans meningsfränder använde den internationella scenen (och erfarenheten av att vara internationell) för att påverka nationella skeenden.

Ett första steg för att besvara frågan är att undersöka sambanden mellan föreningen och deltagandet i IEI. Som redan nämnts finns ett tydligt samband mellan medlemskap i föreningen och IEI. Tabell 1 visar medlemmarna i den svenska IEI-kommittén till vänster och i Föreningen för psykologisk-pedagogiska institutet till höger.

\footnotetext{
40 Fredriksson (1950), 175.

${ }^{41}$ Lundahl (2006).

42 SOU 1929:10, Utredning och förslag rörande praktisk lärarkurs för blivande lärare vid de allmänna läroverken m.fl. undervisningsanstalter.

43 Idén till ett särskilt psykologiskt pedagogiskt institut hade väckts av skolinspektören Frans von Schéele redan 1913. Se Nils Hänninger, "Behöva vi ett psykologiskt-pedagogiskt institut?,” Rostads elevförbunds årsskrift (1935), 60.

44 Se SOU 1938:50, Betänkande angående utbildningen av lärare vid de allmänna läroverken och med dem jämförliga läroanstalter, 33f, 224ff.

45 "Pedagogiska institutet förverkligas," Svensk lärartidning (1934), 1202.

46 "Pedagogisk forskning: Specialnummer i anledning av upprättandet av Psykologisk-pedagogiska institutet," Skola och samhälle 13 (1944), 189-202.
} 
TABELL 1. Personer involverade i den svenska IEI-kommittén och i Föreningen för

\begin{tabular}{|c|c|c|c|}
\hline Namn & Yrkestitel & $\begin{array}{l}\text { Medlem i } \\
\text { Sveriges IEI- } \\
\text { kommitté } 1938\end{array}$ & $\begin{array}{l}\text { Medlem i } \\
\text { Föreningen för } \\
\text { psykologisk- } \\
\text { pedagogiska } \\
\text { institutet 1934 }\end{array}$ \\
\hline Anderberg, A. & F.d. rektor & $\mathrm{X}$ & $\mathrm{X}$ \\
\hline Berg, $\mathbf{H j}$. & F.d. undervisningsråd & & $\mathrm{X}$ \\
\hline Björkquist, M. & Rektor & & $\mathrm{X}$ \\
\hline Edén, E. & Medicinalråd & & $\mathrm{X}$ \\
\hline Grimlund, $\mathbf{H}$. & Rektor & $\mathrm{X}$ & $\mathrm{X}$ \\
\hline Herlitz, C. W. & Docent & & $\mathrm{X}$ \\
\hline Holmdahl, 0. & Generaldirektör (SÖ) & & $\mathrm{X}$ \\
\hline Hänninger, N. & Undervisningsråd & $\mathrm{X}$ & $\mathrm{X}$ \\
\hline Jerneman, T. & Statistik expert, Socialstyrelsen & $\mathrm{X}$ & \\
\hline Jonzon, B. & Folkskoleinspektör & $\mathrm{X}$ & \\
\hline von Koch, G. H. & Kansliråd & & $\mathrm{X}$ \\
\hline Lagercrantz, G. & Bankdirektör & $\mathrm{X}$ & \\
\hline Lichtenstein, A. & Professor & & $\mathrm{X}$ \\
\hline Lundqvist, $\mathbf{N}$. & Rektor & $\mathrm{X}$ & \\
\hline Mattsson, G. & Rektor & $\mathrm{X}$ & \\
\hline Nordlund, K. & Folkskoleinspektör & & $\mathrm{X}$ \\
\hline Orrgård, S. & Huvudlärare & $\mathrm{X}$ & \\
\hline Persson, N. & Folkskoleinspektör & & $\mathrm{X}$ \\
\hline Pettersson, A. C. & Skolföreståndarinna & $\mathrm{X}$ & $\mathrm{X}$ \\
\hline Ramer, T. & Med. lic. & & $\mathrm{X}$ \\
\hline Steenberg, K. & Rektor & $\mathrm{X}$ & $\mathrm{X}$ \\
\hline Sörensen, A. & Rektor & & $\mathrm{X}$ \\
\hline Tunberg, S. & Professor & & $\mathrm{X}$ \\
\hline Wagnersson, $\mathbf{R}$. & Riksdagsman & & $\mathrm{X}$ \\
\hline Wellander, E. & Professor & $\mathrm{X}$ & \\
\hline Wigert, V. & Professor & & $\mathrm{X}$ \\
\hline Wigforss, $F$. & Lektor & $\mathrm{X}$ & $\mathrm{X}$ \\
\hline Wintzell, J. & Fil. dr. & & $\mathrm{X}$ \\
\hline
\end{tabular}

Källa: Svensk lärartidning (1934), 1202; Skola och samhälle 13 (1944), 193.

Tabellen visar att knappt hälften av medlemmarna i den svenska IEI-kommittén också var medlemmar av Föreningen för psykologisk-pedagogiska institutet. Av 13 inblandade personer i svenska IEI ingick sex också i Föreningen för psykologisk-pedagogiska institutet (vilken totalt hade 21 medlemmar).47 Vi kan även se att båda grupperna inkluderade såväl praktiskt som teoretiskt orienterade pedagoger (lärare, rektorer, forskare), skolbyråkrater samt politiskt aktiva. Det är således rimligt att tala om en diskursiv koalition mellan praktiker, forskare, byråkrater och politiker. ${ }^{8}$ Det går att illustrera hur denna koalition verkade rent praktiskt för att etablera och stärka sin position.

47 IEI-ledamoten folkskoleinspektör B. Jonzon blev även medlem i Föreningen för psykologisk-pedagogiska institutet 1944 .

48 Wittrock (1991); Schriewer (2000). 
När Frits Wigforss arbetade med en forskningsstudie inom IEI-projektet vände han sig till Gävle kommun för att få tillgång till lärare som kunde hjälpa honom att undersöka skillnaden mellan folkskolebetyg och inträdesprövningar. En av rektorerna i Gävle var Hildur Nygren. Nygren var också medlem i Föreningen för psykologiskpedagogiska institutet. Föreningen ville att institutet skulle bli till hälften privat och till hälften statligt. Men i ett regeringsförslag menade man att institutet skulle vara helt statligt. I förslaget ingick också att ingen av medlemmarna i föreningen borde få plats i institutets styrelse. Hildur Nygren, nu i kraft av riksdagsledamot, försökte då genom en motion påverka regeringsförslaget. Hon skrev:

Emellertid synes det vara av ett visst värde, att föreningen blir representerad i det tänkta institutets styrelse. Föreningen har som nämnts ej blott i hög grad främjat tanken på ett psykologisk-pedagogiskt institut utan även tagit initiativ till och utfört undersökningar, som visat sig vara av praktisk pedagogisk betydelse i det pågående reformarbetet inom vårt skolväsen. Särskilt kan man i detta hänseende rikta uppmärksamheten på de undersökningar rörande inträdesprövningar och examensväsende, som av föreningen upptagits [...] med finansiellt bistånd från Carnegie Corporation i Förenta staterna. [...] Det synes önskvärt, att samarbete kommer tillstånd mellan föreningen och institutet, icke minst för att föreningens erfarenhet skall tillvaratagas. 49

Nygrens förslag avfärdades initialt av utbildningsutskottet.50 Det kom dock att hörsammas vid ett senare tillfälle. När budgeten för SPPI fastställdes, inte bara höjdes budgeten från 15500 kronor till 85 ooo kronor, utan Frits Wigforss valdes också in som styrelsemedlem..$^{1}$ En av dem som medverkade vid propositionens bifall var finansminister Ernst Wigforss, Frits Wigforss äldre bror.

Den diskursiva koalition som understödde SPPI bestod följaktligen av ett nätverk aktörer med olika möjligheter att påverka beslut och skeenden genom sitt kontaktnät. En annan intressant omständighet var att när SPPI väl realiserats försvann institutets samband till detta nätverk. I den proposition som ledde fram till bildandet av SPPI nämns varken föreningen för institutet eller dess arbete med IEI. ${ }^{52}$ Detta kan jämföras med tidigare utredningar och propositioner där i synnerhet föreningens internationella arbete framhölls som argument för institutets bildande.53 Detta kan förstås som en begynnande politisering av diskursen där politikernas intresse av att framstå som upphovsmakare till en välkommen idé bidrog till att dess egentliga ursprung döljdes. 54 Med andra ord, även om deltagandet i IEI bidrog till att SPPI bildades, kom vare sig IEI eller föreningen för SPPI att tillerkännas något värde i de konstituerande dokumenten. Legitimitetskris har definierats som det tillstånd som inträffar när tidigare

\footnotetext{
49 Andra kammarens protokoll 1944, motion 470, 11-12.

50 Riksdagens protokoll, andra kammaren 24:68d.

51 Proposition 1945:232, 63-66; Riksdagens protokoll, andra kammaren 30:35d; Skola och samhälle (1944).

52 Proposition 1944:207. Detta gäller också för Skolöverstyrelsens synpunkter på vad SPPI borde ha för uppdrag. Se ”Psykologiskt-pedagogiskt institut blir verklighet? Intressant förslag av Skolöverstyrelsen," Svensk lärartidning (1944), 11-12.

53 SOU 1938:50; Prop. 1942:255, 87-101.

54 Jfr Spreen (2004); Florian Waldow, "Undeclared imports: silent borrowing in educational policy-making and research in Sweden,” Journal of comparative education 45, no. 4 (2009), 477-94.
} 
självklara normer förlorar sin giltighet.55 På motsatt sätt kan legitimitet skapas när något görs självklart genom att bakomliggande konflikter blir dolda.

Om än relativt dold fanns alltså en diskursiv koalition bakom bildandet av SPPI. För att ytterligare förstå vad det var denna koalition av progressiva pedagoger ville åstadkomma behöver den placeras in i det svenska utbildningsfältet så som det såg ut under 1930- och 1940-talet.

\section{Det svenska utbildningsfältet under 1930- och 40-talen - behov av enhetlighet}

Frågan om hur svensk skola skulle organiseras var den riktigt stora frågan från 1920till 1950-talet. Under benämningen differentieringsfrågan förekom många meningsutbyten och undersökningar om den lämpligaste skolåldern för att differentiera elevklientelet mellan vidarestudier och yrkesförberedelse. ${ }^{6}$

Differentieringsfrågan hade lyfts fram under 1920-talet men socialdemokratiska regeringar valde att prioritera frågor relaterade till 1920- och 1930-talens ekonomiska regression. Vid slutet av mellankrigstiden såg dock läget annorlunda ut. Ekonomin var bättre och en samlingsregering under ledning av högerpolitikern Gösta Bagge tillträdde. Bagge ansåg att de många olika skolformernas problem var av samma karaktär och borde kunna lösas på ett effektivt sätt om skolan gjordes mer enhetlig. I Sverige fanns vid tiden tolv olika skolformer inom folkskolan och läroverken. Bagge tilltalade de båda politiska blocken när han hävdade att en övergripande lösning på skolans problem bestod i den sammanhållna skolan. Men en sammanhållen skola innebar inte att differentieringsfrågan löstes. I denna fråga fanns fortfarande stor oenighet både mellan de politiska blocken och mellan de två stora lärargrupperna. Läroverkslärare och konservativa politiker föredrog en tidig differentiering, medan vänsterblocket och folkskolelärarna ville ha en senare differentiering. Läroverkslärarna och högern var av uppfattningen att det skulle gagna studenternas intellektuella utveckling om så mycket som möjligt av deras utbildning tillgodosågs av läroverken. Den andra falangen var av uppfattningen att de som inte skulle läsa vidare behövde en gedigen basutbildning. Debatten var emotionellt laddad, bland annat på grund av att de båda lärarkårernas status stod på spel.57

En kompromiss tillkom, på initiativ av socialdemokraten Alva Myrdal, som innebar att differentieringsfrågan skulle lösas med vetenskapliga bevis snarare än med politiska argument eller retorik. En särskild utredning tillsattes och därigenom kom vetenskapssamhället att få avgöra dessa socialpolitiska kontroverser. ${ }^{8}$ Eftersom kunskapsproduktionen på det svenska utbildningsfältet alstrades från disciplinen psykologi och pedagogik kom lösningarnas inriktning att präglas av en för disciplinen typisk epistemologi där experiment och differentiell psykologi dominerade.59 Folkskolelärarna hade mest att vinna på att bevisa att sen differentiering "objektivt" sett

\footnotetext{
55 Hans N. Weiler, "Curriculum Reform and the Legitimation of Educational Objectives: The Case of the Federal Republic of Germany," Oxford Review of Education 16, no. 1 (1990), 15-27.

56 Sixten Marklund, Skolsverige 1950-1975: D. 4: Differentieringsfrågan (Stockholm: Liber förlag, 1985).

57 Se exempelvis Lindensjö och Lundgren (2000), 40-48.

$5^{8}$ Lindensjö och Lundgren (2000).

59 Om man studerar psykologins epistemologi och kvaliteterna av dess språk, dess "fakta och statistik", blir det tydligt att psykologin betraktas som ett snabbt språk. Ett snabbt språk är kodifierat och självrefererande. Det inte bara framträder snabbare utan är också snabbare genom att vara icke-överläggande (dvs. objektivt). Det förbinder effektivt flera olika intressegrupper med ett "otvetydigt lingua”. Det blir enkelt att avkoda för den som
} 
var bättre, och de kom därför också att välkomna den experimentella och differentiella psykologin i det praktiska läroplansarbetet.

Psykologi och pedagogik hade blivit en egen disciplin 1907 och kom successivt att influera både folkskole- och läroverkslärarutbildningen. ${ }^{60}$ Men det var i relation till differentieringsfrågan som den psykologiska diskursen kom att bli dominerande på utbildningsfältet, särskilt i förhållande till folkskolan och till frågor om mätning och bedömning av elevers kunskaper. I folkskolelärarnas fackliga tidskrifter från 1930- och 40-talen är det exempelvis tydligt att bruket av ett psykologiskt språk och spridningen av psykologiska resultat ökar och så småningom ersätter den pedagogiska praktikens språk kring dessa frågor. Denna utveckling var inte lika tydlig i läroverkslärarnas tidskrifter. ${ }^{61}$ Detta förhållande gäller också omnämnandet av IEI och SPPI, vilka inte alls diskuteras i den största läroverkstidningen Tidning för Sveriges Läroverk, men ges en hel del uppmärksamhet i folkskolans tidskrifter. Med andra ord framträder enhetliggörandet av skolsystemet som en större angelägenhet för den lärarkår som hade lägre status.

Genom att närmare studera artiklar i folkskollärarnas tidskrifter framträder en komplex bild av det svenska utbildningsfältet och därigenom den funktion en psykologisk diskurs tänktes kunna fylla. ${ }^{62}$ Utbildningsfältet var fragmenterat och SPPI sågs som en institution som skulle kunna bidra till ett enhetliggörande.

Nils Hänninger tog upp den tanken i en kommentar till 1927 års skolutredning. Han föreslog ett institut som skulle verka för att knyta pedagogisk praktik närmare psykologisk och pedagogisk teori. Ett sådant institut skulle också bli en mötesplats för alla de olika aktörer som så att säga utgjorde skolans infrastruktur.

Över huvud taget behöves det en gemensam plattform för diskussion och övervägande - och undersökning - av de mångskiftande uppfostringsproblem, som nutidens skola ställer. Det gäller t.ex. om förhållandet mellan medicinskpsykologisk och pedagogisk verksamhet. [...] Ett pedagogiskt institut skulle skapa en mötesplats för de medicinska och de pedagogiska intressena. ${ }^{63}$

Det fragmenterade utbildningssystemet bestod av olika intresseorganisationer, lärarutbildningsvägar och lärarförbund vilka hade skilda sätt att se på skolan och olika sätt att tala om den. Det var inte bara skolans inre organisation som behövde ses över utan även dess "yttre organisation" borde göras mer enhetlig. Det var i alla fall så Hänninger och de övriga medlemmarna i Föreningen för psykologisk-pedagogiska institutet argumenterade. I en artikel om bildandet av föreningen preciseras behovet av sammanhållning när det gällde den yttre organisationen:

\footnotetext{
lärt sig "språket". Jfr Lundahl (2006), kap. 12; Lundahl (2009); Lundahl och Waldow (2009). Att tro på och arbeta utifrån det snabba språkets rationalitet är att reducera komplexiteten i ett system. Jfr Eva Forsberg och Christian Lundahl, "Kunskapsbedömningar som styrmedia," Utbildning \& demokrati 3 (2006), 7-30; Christian Ydesén, Kari Ludvigsen och Christian Lundahl, "Creating an Educational Testing Profession in Norway, Sweden, and Denmark, 1910-1960," European Educational Research Journal 12, no. 1 (2013), 12938.

60 Fransson och Lundgren (2003); Berit Askling, Utbildningsvetenskap - ett vetenskapsområde tar form (Stockholm: Vetenskapsrådet, 2006).

${ }^{61}$ Lundahl (2006), del 3.

62 Svensk lärartidning (1934), 1202; Svensk lärartidning (1944), 11-2; Svensk lärartidning (1944), 1216; Skolan och Samhälle (1944), 189-202.

63 Hänninger (1935), 60-63.
} 
Kommittén har funnit det särskilt angeläget, att en organiserad samverkan åstadkommes mellan de institutioner av olika slag, som redan har pedagogiska uppgifter. För åstadkommande av en dylik samverkan och för planens fullföljande i övrigt har kommittén tänkt sig ett pedagogiskt institut med följande huvuduppgifter: att befrämja psykologisk-pedagogisk forskning, med tillbörlig hänsyn även till medicinska synpunkter, och i samband därmed utöva ledningen av ett pedagogiskt bibliotek, ett muséum [sic!] och en institutets skola; anordna kurser och föreläsningar för fortsatt utbildning av lärare och vid behov anordna grundläggande lärarutbildning, samt utbildning för verksamhet inom olika slag av barnavård och ungdomsskydd; bedriva upplysningsarbete bland allmänheten rörande pedagogiska frågor. ${ }^{64}$

Det svenska utbildningsfältet runt 1940 kan beskrivas som uppbyggt kring flera olika organisationer. Folkskolan bestod av sju olika skolformer och läroverket av fem. Det fanns olika vägar till läraryrket, via folkskoleseminariet eller universitetet. Utbildningsfältet var således kraftigt fragmenterat. I detta landskap behövdes sammanbindande institutioner och det var just det SPPI föreslogs bli, en sammanhållande länk och en plattform för diskussion, överväganden och nya undersökningar. En av uppgifterna var att ta fram kunskaper om elevers inlärning och prestationer, och därigenom också skapa ett gemensamt (centralt) språk, den psykometriska diskursen, för de olika aktörerna i skolans infrastruktur. Standardprov var ett instrument som erbjöd ett sådant sammanbindande "språk". Skolmognadsprov var ett annat likartat instrument. I och med dessa prov sattes elevresultaten i förgrunden för diskussionen. SPPI genomförde även stora utbildningssatsningar i intelligensmätningsteknik för lärare. ${ }^{65}$ I viss mening var institutet en import av liknande lösningar utomlands. Genom deltagandet i IEI kunde Hänninger och föreningen peka på att liknande institut hade upprättats i Skottland, USA och Tyskland. ${ }^{66}$ IEI-projektet främjade således bildandet av institutet genom möjligheten att låna in modeller från utlandet, men deltagandet i IEI gav också ordentligt med resurser för att i större skala pröva Wigforss standardprov. Detta var en typ av forsknings- och utvecklingsarbete som senare föreslogs bli en av institutets innehållsliga huvuduppgifter. ${ }^{67}$

Hänninger betonade, som visats ovan, vikten av institutet som mötesplats. Wigforss betonade i stället att denna mötesplats borde ha en standardiserande funktion och han diskuterade möjligheten att normalisera lärares bedömningar:

Uniformity in [Arithmetic] would obviously have been gained if the certificates had been awarded according to the verdict of the standard tests, but the question is whether such a method would be justified. To what extent can one be sure that the verdict of the tests is the right one? The trustworthiness of a test depends on how well the test is related to that which is the object of testing (i. e. the curriculum) and the suitability of the test as a measuring instrument. ${ }^{68}$

\footnotetext{
64 Svensk lärartidning (1934), 1202.

65 Se vidare Lundahl (2006).

66 Hänninger (1935).

67 Prop. 1942:255.

68 Wigforss (1941), 127. Det kan vara värt att nämna att den här rapporten byggde på data som Wigforss och hans kollegor samlade in mellan 1929 och 1937. Med andra ord finansierade inte Carnegie Corporation själva undersökningen utan bara sammanställningen och publiceringen av den. Som hävdats ovan följde de svenska rapporterna en nationell tradition av att undersöka urvals- och inträdesfrågor, men Carnegie-pengarna var ett
} 
Genom att relatera standardprov till läroplanen (eller vice versa) och försäkra sig om att lärares bedömningar följer samma standard, skulle det bli möjligt att reducera komplexiteten i systemet enormt. Inträdesprövningar kunde tas bort. Att utveckla den här typen av rationaliserande prov blev en av de viktigaste uppgifterna som tillskrevs SPPI under dess första år. Standardproven är således ett exempel på enhetliggörande språk. Wigforss fick huvudansvaret för standardproven men också för att utveckla så kallade skolmognadsprov med syftet att kunna kalibrera kursplanerna efter vad den "normala" 7-åringen kunde förväntas prestera.

SPPI:s tillkomst kan i backspegeln förstås som formeringen av en ny typ av central styrning och centrala styrinstrument. Det är ett styrinstrument som bygger på produktionen av psykometrisk information, eller i Anthony Giddens mening en "institutionaliserad reflexivitet”. SPPI är i vid bemärkelse ett exempel på att det moderna samhället börjar kräva riktade kunskaper inom vissa sektorer. ${ }^{69} \mathrm{Med}$ en sådan tolkning går det att betrakta SPPI som ett komplement till dåtidens fakulteter och till Skolöverstyrelsen. Den skotska motsvarigheten till Statens psykologisk-pedagogiska institut, SCRE, har beskrivits som å ena sidan en institution vilken tog hand om en kunskapsproduktion som universiteten ansåg sig alltför politiskt obundna för att tillhandahålla, och å andra sidan en institution som tog hand om "moderna" frågor vilka skolbyråkratin inte utvecklats för. ${ }^{70}$ Kanske var det så att SPPI skapades för att befintliga skolmyndigheter inte tillräckligt drev moderniseringen av skolan framåt.

Detta leder tillbaka till huvudsyftet för artikeln. Det är tydligt att SPPI tillkom för att fylla en enhetliggörande funktion. Frågan är nu hur Sveriges deltagande i IEI bidrog till denna utveckling. Svaret på frågan ger en indikation på i vilken utsträckning nationella reformer formas av internationella rörelser och/eller utifrån nationella behov.

\section{Effekten av deltagandet i IEI på den svenska läroplanen}

Det råder ingen tvekan om att SPPI och i synnerhet de undersökningar som Frits Wigforss gjorde om bedömning och prov har påverkat utvecklingen av den svenska läroplanen.71 Jag har illustrerat hur Föreningen för psykologisk-pedagogiska institutet arbetade för realiserandet av SPPI och hur SPPI kunde tjäna vissa behov i ett moderniserat svenskt utbildningssystem. När det gäller i vilken utsträckning som IEI bidrog till att realisera SPPI måste man först komma ihåg att även om det inte fanns någon direkt opposition mot SPPI, så fanns starka intressen mot den modernisering som SPPI representerade. Framför allt skulle läroverkslärarna förlora rätten att välja ut de elever de skulle undervisa. De kunde också se att de förlorade en del autonomi över utbildningen. Psykologer, medicinare, forskare i pedagogik trädde in på utbildningsfältet på ett aldrig tidigare skådat vis. ${ }^{72}$ Lärarkårerna såg hur en lång tradition av att "göra skola" var hotad. Deras erfarenheter av hur undervisning och lärande borde iscensättas skulle få mindre värde. För att övertyga personer som såg en fara i detta

välkommet bidrag. Se Frits Wigforss, A paper on the awarding of marks and certificates in the primary school and the possibility of normalizing the awards (Stockholm: Norstedts, 1941), 3-6.

${ }^{69}$ Folkhälsoinstitutet och Arbetslivsinstitutet är senare exempel på samma sak.

70 Martin Lawn, "The Institute as Network: The Scottish Council for Research in Education as a Local and International Phenomenon in the 1930s," Paedagogica Historica 40, no. 5-6 (2004), 719-32.

${ }^{71}$ Kilpatrick och Johansson (1994); Lundahl (2006).

72 Jfr Lundahl (2006). 
kunde internationella trender och erfarenheter från internationella konferenser verka som en kraftfull strategi - utan att någon faktiskt idéimport ägt rum. Att verka världsvan kan ge legitimitet på hemmaarenan.73

I olika lärartidskrifter och i statliga rapporter och propositioner är det möjligt att se två huvudstrategier avseende hur deltagande i IEI åberopades för att driva nationell läroplansförändring. Den första strategin har att göra med inträdesexaminationer och prövningar. Wigforss hänvisade relativt utförligt till det svenska deltagandet i IEI i sin utredning om standardiserade betyg. Särskilt Orrgårds studie gavs stort utrymme. ${ }^{74}$ Svenska resultat, men i synnerhet situationen i andra deltagarländer, användes i inflytelserika tidskrifter i argumentationen mot traditionella examinationer och inträdesprövningar.75 I en intervju direkt efter Dinard-konferensen kommenterade Hänninger de problem som flera av de andra IEI-länderna stod inför gällande "yttre examensnämnder":

Hos oss i Sverige har vi ju inte sådana nämnder [yttre examensnämnder], det är t.ex. inte censorerna utan lärarna, som sätter betyg i studentexamen. I samband med den senaste studentexamensutredningen föreslogs inrättandet av nämnder. Jag opponerade mig då med tanke på erfarenheterna från andra länder [Hänninger syftar på England, France och Finland]. ${ }^{76}$

Det är tydligt att den internationella erfarenheten kunde användas för att avfärda vissa alternativ som kom upp i den svenska diskussionen. Men utöver detta, kan de resultat som de andra länderna presenterade vid IEI-konferenseran knappast ha överraskat den svenska delegationen. Tidigare och parallella nationella undersökningar hade ofta kommit till samma slutsatser som presenterades vid IEI, exempelvis de subjektiva inslagen vid inträdesprövningar 77 eller om det överskattade värdet av intelligenstestningar. ${ }^{78}$ Samtidigt verkar det ha varit viktigt att informera om erfarenheten från IEI, och man kan undra varför om det nu inte framkommit något nytt. Två skäl framträder som självklara. Dels måste det ha funnits en attraktion i att stärka den egna diskursiva positionen med hjälp av eller i kontrast till andra länder. Dels hade de personer som var inblandade i den svenska delegationen den faktiska möjligheten att ge uttryck för sina erfarenheter, eftersom flera av dem också var redaktörer i inflytelserika tidskrifter. Med andra ord: den första effekten av deltagandet i IEI handlade om möjligheten att stärka en existerande progressiv diskurs och samtidigt utesluta hotande alternativ.

Ytterligare en tydlig effekt av deltagandet i IEI är relaterad till behovet av ett psykologisk-pedagogiskt institut som kunde reproducera denna diskurs - en modern institution som förmådde knyta vetenskap och pedagogisk praktik närmare varandra. Här kunde IEI-studierna användas som exempel på en typ av arbete som borde utföras av SPPI. Deltagandet i IEI gav också delegationens medlemmar kunskaper om att liknande institut som SPPI fanns i andra länder: Zentralinstitut für Erziehung und

\footnotetext{
73 Se även Lundahl och Lawn (2013).

74 SOU 1938:29, 43-60.

75 Svensk lärartidning (1936), 4-5; Svensk lärartidning (1938), 1046; Hänninger (1935), 60; Psykologisk pedagogisk uppslagsbok (1943), 430ff; Skola och samhälle (1944).

76 Svensk lärartidning (1938), 1046. Temat diskuterades omsorgsfullt på konferensen. Monroe (1939).

77 Hänninger (1932).

78 Skolkommissionens betänkande 1921-1923; Hänninger (1922); Svensk lärartidning (1931), 1179-80.
} 
Unterricht in Berlin, Teachers' College i New York och The Scottish Council for Research in Education fungerade som inspirationskällor. ${ }^{79}$ Hänvisningar till dessa institut finns också i propositionen för SPPI. ${ }^{80}$ Dess betydelse är förstås svår att mäta. Ett visst materiellt mått på betydelsen av IEI är de 3000 dollar Föreningen för psykologisk-pedagogiska institutet fick från Carnegie, vilket motsvarade ungefär det belopp som SPPI fick för sitt första verksamhetsår. ${ }^{81}$ Deltagandet i IEI bidrog till att göra Föreningen för pedagogisk-psykologiska institutet till en ekonomiskt stark aktör med resurser att sprida sin diskurs, vilket i förlängningen inte minst främjade realiserandet av SPPI.

\section{Sammanfattande slutsatser}

Artikeln inleddes med hävdandet att deltagandet i IEI inte påverkade den svenska diskursen om bedömning, åtminstone inte sett till dess grundläggande idéer. Däremot är det tydligt att deltagandet påverkade diskursen på flera andra sätt. Det bidrog till att hjälpa ett reformivrande nätverk att systematisera och publicera resultat som gav stöd för ett övergivande av inträdesprövningar. Deltagandet hjälpte nätverket att stärka sin position på det svenska utbildningsfältet då de kunde framstå som resande, världsvana personer med perspektiv. Deltagandet fungerade också som argument för ett psykologisk-pedagogiskt institut genom att visa hur teori och praktik kunde förenas, och att de institut som fanns i andra länder fungerade som plattform för enhetliggörande av utbildningssystem.

De nio länder som under 1930-talet var med i IEI-projektet hade stått inför liknande problem som fanns i Sverige. De ville göra högre grundutbildning mer tillgänglig och de ville att övergången från lägre studieår till högre skulle ske effektivt och rättvist. De europeiska länderna hade gemensamt att skolan var organiserad i parallella skolformer och att lärarna på den högre utbildningen genom inträdesprövningar själva valde ut vilka studenter som skulle antas. I USA var skolsystemet mer enhetligt och man hade inte Europas gamla läroverkstradition. Amerikanerna hade med viss framgång börjat organisera inträdesprövningen genom vetenskapliga test. Detta ville de sprida till européerna. Med facit i hand nappade England och Skottland medan de övriga länderna - utom Sverige - fortsatte att organisera övergången genom traditionella inträdesprövningar. ${ }^{82}$ Sverige valde en i sammanhanget unik riktning; man lät standardproven normera lärarnas betygssättning och därmed kunde betygen användas i stället för både vetenskapliga test och inträdesprövningar. ${ }^{83}$ Prov och betyg var i Sverige, inte som i exempelvis England och Skottland, utmanade av vetenskapliga tester. Det var med andra ord alltjämt lärarna och inte vetenskapsmännen som fick styra över elevernas livschanser.

Det går med andra ord inte att hävda att Sveriges relation till IEI är ett exempel på hur anglo-saxisk psykologi koloniserade svenskt utbildningstänkande. Vad svenskarna förmodligen var mest intresserade av att importera var idén om skolväsendets enhetlighet. Genom att enhetliggöra det svenska utbildningssystemet reducerades komplexiteten i det. Ett medel att göra det mer enhetligt ansågs dock ligga i de psykologisk

\footnotetext{
79 Hänninger (1935), 62; SOU 1938:50, 224; Svensk skoltidning 50 (1944), 7.

80 Prop. 1942:255, 95.

${ }^{81}$ Svensk lärartidning (1936), 5 .

82 Lawn (2008).

83 Lundahl (2008).
} 
inspirerade kunskapsmätningarna. Psykologiseringen av utbildningsdiskursen var således inte ett mål i sig utan ett medel för effektivisering och sammanhållning. Både Hänninger och Wigforss påpekade ofta att det psykologiska tänkandet skulle utgå från den pedagogiska praktikens behov, inte styra arbetet i skolan.

Men bilden av en koloniserande psykologi kan ändå ses som passande för att förstå den svenska utbildningsdiskursen under 1950- och 1960-talen. Utbildningsdiskursen i Sverige blev framgent mer politisk och i relation till det också mer vetenskaplig. Politikerna använde $\mathrm{i}$ allt högre utsträckning vetenskapen för att legitimera sina beslut. Detta till trots tonades SPPI:s ursprung i föreningen och IEI ned när institutet väl realiserats.

Det blir vid något tillfälle viktigt för politikerna att få idéer att framstå som deras egna. ${ }^{84}$ Det handlar om legitimitet, men det är också rimligt att anta att när väl de centrala besluten är tagna blir det av större betydelse att visa (gärna med hjälp av kulturellt starka symboler som statistik) att reformerna gett önskade effekter. Då spelar det plötsligt mindre roll vad man gör i andra länder. I flera decennier efter andra världskriget kom en starkt psykologiskt sifferpräglad pedagogik att vända blicken inåt det egna systemet snarare än att titta utåt mot den internationella scenen. Detta bidrog till en läroplansorientering som bar tydliga märken av social ingenjörskonst:

Swedish behavioural research at the outset of the 1950s, irrespective of whether it carried an educational or psychological label, was essentially marketed as social engineering, which more or less amounted to telling people what they were good for. It could help to predict who was going to be able to cope with higher education or demonstrate aptitude for certain occupations. ${ }^{85}$

Under SPPI:s första tio verksamhetsår använde regeringen institutet för att lansera psykologiska test och för att utbilda lärare i psykologi (Lundahl 2006). Wigforss position förlorade mark och när han dog 1953 hade mycket av hans tänkande om att utveckla snarare än ersätta lärares omdömen glömts bort. ${ }^{86}$ År 1949 skrev Folkskolan på ledarsidan att lärarkåren var besvikna över vad som hade blivit av SPPI. Institutet hade blivit för teoretiskt för att kunna tjäna det praktiska arbetet i skolan. Progressiva pedagoger hade - tvärt emot deras ursprungliga intentioner - lagt grunden till en psykologisk kolonisering av utbildningsfältet, och därmed till en de-professionalisering av lärarkåren. På vägen mot detta hade deltagandet i IEI spelat en betydelsefull roll.

\footnotetext{
84 Jfr Spreen (2004).

85 Torsten Husén, “Two decades of educational research," i Social Science Research in Sweden (Stockholm: Statens råd för samhällsforskning, 1972), 234.

86 Kilpatrick och Johansson (1994); Lundahl (2009).
} 


\section{Referenser}

Askling, Berit. Utbildningsvetenskap: Ett vetenskapsområde tar form. Stockholm: Vetenskapsrådet, 2006.

Elgqvist-Saltzman, Inga. Lärarinna, kvinna, människa. Stockholm: Carlssons förlag, 1993.

Forsberg, Eva och Christian Lundahl. "Kunskapsbedömningar som styrmedia". Utbildning \& demokrati 3 (2006), 7-30.

Fransson, Karin och Ulf P. Lundgren. Utbildningsvetenskap - ett begrepp och dess sammanhang. Stockholm: Vetenskapsrådet 2003.

Fredriksson, Viktor red. Svenska folkskolans historia, vol. V: Det svenska skolundervisningsväsendet 1920-1942. Stockholm: Albert Bonniers förlag, 1950.

Giddens, Anthony. Modernity and Self-Identity: Self and Society in the Late Modern Age. Stanford: Stanford University Press, 1991.

Husén, Torsten. "Two Decades of Educational Research." I Social Science Research in Sweden. Stockholm: Statens råd för samhällsforskning, 1972.

Hänninger, Nils. Den amerikanska uppfostringsvärlden: Studier och strövtåg. Stockholm: Norstedts, 1922.

Hänninger, Nils. ”Examen och skolarbete”. Skola och samhälle (1932), 185-194.

Hänninger, Nils. ”Behöva vi ett psykologiskt-pedagogiskt institut?” Rostads elevförbunds årsskrift (1935), 60-63.

Kilpatrick, Jeremy och Bengt Johansson. "Standardized mathematics testing in Sweden: The legacy of Frits Wigforss." NOMAD: Nordic Studies in Mathematics Education 2 no. 1 (1994), 6-30.

Lawn, Martin. "The Institute as Network: The Scottish Council for Research in Education as a Local and International Phenomenon in the 1930s.” Paedagogica Historica 40, no. 5-6 (2004), 719-32

Lawn, Martin red. An Atlantic Crossing? The Work of the International Examinations Inquiry, its Researchers, Methods and Influence. Oxford: Symposium Books, 2008.

Lindensjö, Bo. och Ulf P. Lundgren. Utbildningsreformer och politisk styrning. Stockholm: HLS Förlag, 2000.

Lundahl, Christian. Viljan att veta vad andra vet. Kunskapsbedömning i tidigmodern, modern och senmodern skola. Stockholm: Arbetslivsinstitutet, 2006.

Lundahl, Christian. "Inter/National Assessments as National Curriculum: The Case of Sweden.” I An Atlantic Crossing? The work of the International Examination Inquiry, its researchers, methods and influence, red. Martin Lawn. Oxford: Symposium Books, 2008.

Lundahl, Christian. Varför nationella prov? Framväxt, dilemman, utmaningar. Lund: Studentlitteratur, 2009.

Lundahl, Christian och Florian Waldow. "Standardisation and 'quick languages': The shape-shifting of standardised measurement of pupil achievement in Sweden and Germany.” Journal of Comparative Education 45, no. 3 (2009), 365-85.

Lundahl, Christian och Martin Lawn. "The Swedish Schoolhouse at the 1860 - 1870s World's fairs - Between Myth and Reality”. [opublicerad 2013].

Lundgren, Ulf P. Frame Factors and the Teaching Process: A Contribution to Curriculum Theory and Theory on Teaching. Stockholm: Almqvist \& Wiksell, 1972.

Lundgren, Ulf P. Att organisera omvärlden. En introduktion till läroplansteori. Lund: Liber, 1979. 
Marklund, Sixten. Skolsverige 1950-1975: D. 4: Differentieringsfrågan. Stockholm: Liber Utbildningsförlag, 1985.

Meyer, John W. och Brian Rowan. "Institutionalized Organizations: Formal Structure as Myth and Ceremony." The American Journal of Sociology, 83, no. 2 (1977), 34063.

Monroe, Paul. red. Conference on Examinations: Under the Auspieces of the Carnegie Corporation, The Carnegie Foundation and The International Institute of Teachers College Columbia University. New York: Colombia University, 1931.

Monroe, Paul. red. Conference on Examinations (Dinard, France, September 16-19, 1938). New York: Teachers College Columbia University, 1939.

Psykologisk pedagogisk uppslagsbok. "Examensundersökningar." Stockholm: Bokförlaget Natur och kultur, 1943.

Riksdagstryck, andra kammaren, motion 470 (1944).

Riksdagstryck, Proposition 1942:255.

Riksdagstryck, Proposition 1944:207.

Riksdagstryck, Proposition 1945:232.

Riksdagstryck, protokoll, andra kammaren 24:68d (1944).

Riksdagstryck, protokoll, andra kammaren 30:35d (1945).

Rostads elevförbunds årsskrift (1930). Rostad.

Schriewer, Jürgen. "Educational Studies in Europe." I Problems and Prospects in European Education, red. Elisabeth S. Swing, Jürgen Schriewer och François Orivel, s. 72-95. London: Praeger, 2000.

Schriewer, Jürgen. "Multiple Internationalities: The Emergence of a World-Level Ideology and the Persistence of Idiosyncratic World-Views." I Transnational Intellectual Networks: Forms of Academic Knowledge and the Search for Cultural Identities, red. Christophe Charle, Jürgen Schriewer och Peter Wagner, 473-533. Frankfurt: Campus 2004.

Skola och samhälle 13 (1944). "Pedagogisk forskning. Specialnummer i anledning av upprättandet av Psykologisk-pedagogiska institutet," 189-202.

Skolkommissionens betänkande, 1921-1923. [1918 års skolkommission] Stockholm.

SOU 1929:10. Utredning och förslag rörande praktisk lärarkurs för blivande lärare vid de allmänna läroverken $\mathrm{m}$. $\mathrm{fl}$. undervisningsanstalter. Stockholm: Ecklesiastikdepartementet.

SOU 1938:29. Betänkande med utredning och förslag angående intagning av elever i första klassen av de allmänna läroverken och med dem jämförliga läroanstalter. Stockholm: Ecklesiastikdepartementet.

SOU 1938:50. Betänkande angående utbildningen av lärare vid de allmänna läroverken och med dem jämförliga läroanstalter. 1936 års lärarutbildningssakkunniga. Stockholm: Ecklesiastikdepartementet.

SOU 1942:11. Betänkande med utredning och förslag angående betygssättningen $i$ Folkskolan. Stockholm: Ecklesiastikdepartementet.

SOU 1943:19. Den psykologiska forskningens nuvarande ståndpunkt i fråga om den psykiska utvecklingen hos barn och ungdom m.m. Stockholm: Ecklesiastikdepartementet.

Spreen, Carol Ann. "Appropriating Borrowed Policies: Outcomes-Based Education in South Africa." I The Global Politics of Educational Borrowing and Lending, red. Gita Steiner-Kamsi, 101-13. New York: Teachers College Press, 2004. 
Steiner-Kamsi, Gita red. The Global Politics of Educational Borrowing and Lending. New York och London: Teachers College Press, 2004.

Svensk lärartidning (1931). "Inträdesproven till läroverken".

Svensk lärartidning (1934). "Pedagogiska institutet förverkligas".

Svensk lärartidning (1936). "Hur stort värde har ett examensbetyg? Engelsk undersökning ger häpnadsväckande resultat".

Svensk lärartidning (1936). "Föreningen för psykologisk-pedagogiska institutet".

Svensk lärartidning (1938). "Examensproblemet ventileras. Internationell konferens med svenska representanter".

Svensk lärartidning (1944). "Psykologiskt-pedagogiskt institut blir verklighet? Intressant förslag av Skolöverstyrelsen".

Svensk lärartidning (1944). ”Aktuellt på skolfronten: Psykologisk-pedagogiskt institut 1 november".

Svensk skoltidning 50 (1944) "Psykologisk-pedagogiska institutet sätter igång".

Orrgård, Sixten. High school entrance-tests and the work of the primary-school: A Swedish nation-wide investigation in 1936. Stockholm: Norstedts, 1937.

Waldow, Florian. "Undeclared imports: silent borrowing in educational policy-making and research in Sweden.” Journal of comparative education 45, no.4 (2009), 47794.

Weiler, Hans N. "Curriculum Reform and the Legitimation of Educational Objectives: The Case of the Federal Republic of Germany." Oxford Review of Education 16, no. 1 (1990), 15-27.

Wigforss, Frits. "Rostads standardprov i sifferräkning." Rostads elevförbunds årsskrift 28 (1931), 86-100.

Wigforss, Frits. "Färdigheten i mekanisk räkning i folkskolan enligt Rostads standardtabeller." Skolan och samhälle 14 (1933), 191-222.

Wigforss, Frits. The entrance examination in view of later school performances. Stockholm: Norstedts, 1937.

Wigforss, Frits. A paper on the awarding of marks and certificates in the primary school and the possibility of normalizing the awards. Stockholm: Norstedts, 1941.

Wittrock, Björn, Peter Wagner och Hellmut Wollman. "Social Science and the Modern State: Policy Knowledge and Political Institutions in Western Europe and the United States.” I Social Sciences and Modern States. National Experiences and Theoretical Crossroads, red. Peter Wagner et al., 28-85. Cambridge: Cambridge University Press, 1991.

Ydesén, Christian, Kari Ludvigsen och Christian Lundahl. "Creating an Educational Testing Profession in Norway, Sweden, and Denmark, 1910-1960." European Educational Research Journal (2013), 120-38. 